\title{
Detection of Porcine Cysticercosis in Nagaland of North East, India
}

\author{
Acheenta G. Barua*, Koushik Kakoty, Pranjal M. Nath and Nur Abdul Kader \\ Department of Veterinary Public Health, College of Veterinary Science, Assam Agricultural \\ University, Khanapara, Guwahati-781022, India \\ *Corresponding author
}

\section{A B S T R A C T}

Keywords

Pig, Nagaland, Cysticercuscellulos ae, $\mathrm{PCR}$,

Taeniasolium

Article Info

Accepted:

22 July 2019

Available Online:

10 August 2019
A total of 360 pig carcasses were examined through meat inspection in different market places of Dimapur and Kohima district of Nagaland, India in the month of March, 2019. Out of which, 6 (1.67\%) were found positive for porcine cysticercosis with visible cysts. The serum samples were collected from 300 pigs and out of which 10 (3.00\%) serum samples were found positive for Cysticercus cellulosae antibody. Polymerase chain reaction (PCR) assay was performed to confirm Cysticercus cellulosae and to validate the results of meat inspection. Oligonucleotide primers targeting against the large subunit rRNA gene (TBR primers) of Taenia solium were used in this study. On reactivity in PCR test, the TBR primers yielded products of $286 \mathrm{bp}$ in cysticercosis positive cases.

\section{Introduction}

Cysticercus cellulosae, the metacestode stage of Taenia solium is an underrated and a neglected zoonotic disease involving pig and man (Willingham et al., 2008). Porcine cysticercosis plays a crucial role in the transmission and maintenance of human taeniosis and cysticercosis (Pinto et al., 2000). In Indian context, meat consumption is greatly influenced by culture, traditions, customs and taboos especially in the rural societies. In north eastern states of India pork is considered as a traditional food item (Anonymous. 2012) and has much higher pork consumption than the other parts of the country. The demand for pork was increasing along with prices in both Assam and Nagaland according to the traders. Thus, accurate inspection of pork is very important.

Although the pork consumption is highest in North East India but the scientific procedure of diagnosis and meat inspection is still lacking. While meat inspection is the preferred diagnostic tool to detect heavily infected carcasses but it is not reliable in detecting lightly infected carcasses (Cai et al., 2006). So detection of antibodies by ELISA (Ab-ELISA) can be used as an alternative tool for the diagnosis of porcine cysticercosis (Deckers et al., 2008). 
Moreover, meat inspection requires expertise of the meat inspector; otherwise cysticerci may be confused with $T$. hydatigena cysticerci (Kedra et al., 2001), hydatid cysts (Deplazes et al., 2005) and left over of muscle fasciae (Geysen et al., 2007). To overcome such type of difficulties application of ELISA and molecular tools like Polymerase chain reaction (PCR) can be effective in diagnosis and validation of meat inspection results.

So considering the public health significance of the disease, the purpose of this study was to evaluate the performance of ELISA for antemortem diagnosis in pigs and estimating the prevalence of porcine cysticercosis in slaughtered pig through meat inspection and PCR for validation of results.

\section{Materials and Methods}

\section{Study area}

The study was carried out between January 2019 to February 2019 in Dimapur and Kohima district of Nagaland, India. Three blocks from each district were selected for collection of sera sample and for carcass examination.

\section{Sample collection}

\section{Collection of blood samples}

A total of 300blood samples were collected from the anterior vena cava of pigs by using BDV accutainer@needles (gauge 19) and BDV acutainer®plain tubes $(10 \mathrm{ml})$. The blood samples were kept standing in an ice box at $+4{ }^{\circ} \mathrm{C}$ to ensure no haemolysis occurred while in the field.

At the laboratory, blood was centrifuged to separate serum from blood clot. Serum was harvested into barcoded $2 \mathrm{ml}$ vials that were stored at $-20 \circ \mathrm{C}$ until processing.

\section{Carcass Inspection}

A total of 360 pig carcasses were examined as per the standard method [10] for the presence of Cysticercus cellulosae from different market places of Dimapur and Kohima district. Majority of the pigs were brought from Uttar Pradesh, India to Dimapur and distributed to the rest of the districts of Nagaland on weekly basis (Fig.1). Fifty gram (g) of tissue each from brain, tongue, liver and skeletal muscles of infected pig carcasses were brought to the laboratory in ice-box

\section{Serological tests}

ELISA was performed as per the manufacturer's protocol of RIDASCREEN ${ }^{\circledR}$ Taenia solium IgG kit (RBiopharm AG, Germany). The absorbance was read at 450 nm with an ELISA reader (Lab systems Multiskan Plus, Thermo Fisher Scientific, USA). Samples having percent positivity value 0.50 or above $(\% \mathrm{P} \geq 0.05)$ were categorized as positive and below 0.50 as negative.

\section{Extraction of DNA from cysts}

Extraction of DNA from cysts/suspected lesion was made possible using a commercially available QIAamp tissue kit (QIAGEN, Hilden, Germany) according to the manufacturer's instructions (Kolesarova et al., 2012). Briefly, $200 \mu \mathrm{l}$ of cyst/lesion homogenate, $20 \mu \mathrm{l}$ of proteinase $\mathrm{K}$ stock solution, and $200 \mu \mathrm{l}$ of lysing buffer were pipetted into $1.5 \mathrm{ml}$ Eppendorf tube. The mixture was incubated at $37{ }^{\circ} \mathrm{C}$ for $1 \mathrm{~h}$ and then at $70{ }^{\circ} \mathrm{C}$ for $30 \mathrm{~min}$ before the addition of $200 \mu \mathrm{l}$ of absolute alcohol and mixing by vortexing. The mixture was then transferred to the QIAamp spin column placed in a clean 2 ml collection tube and centrifuged at 8000 RPM in MiniSpin centrifuge (Eppendorf, Wesseling-Berzdorf, Germany) for $1 \mathrm{~min}$ at 
room temperature. The QIAamp spin column was washed twice with $500 \mu \mathrm{l}$ of the washing buffers by spinning for $1 \mathrm{~min}$. The QIAamp spin column was placed in a clean $1.5 \mathrm{ml}$ eppendorf tube and the DNA was eluted with $100 \mu \mathrm{l}$ of elution buffer preheated at $70{ }^{\circ} \mathrm{C}$. Maximum DNA yield was obtained by spinning at $12,000 \mathrm{rpm}$ for $1 \mathrm{~min}$ at room temperature. From the suspended nucleic acid $5 \mu \mathrm{l}$ was used in the PCR amplification. The extracted DNA was quantified using spectrophotometer at $260 \mathrm{~nm}$ wave length

\section{Oligonucleotide primers}

The oligonucleotide primers specific to $T$. solium were adopted from already published sequences. The primers TBR3 (5'-GGC TTG TTT GAATGG TTT GAC G-3) and TBR-6 (5'-GCT ACTACA CCT AAA TTC TAA CC3) against large subunit rRNA gene (Jardim et al., 2006).

\section{PCR amplification and detection of PCR product}

The PCR reaction was performed in a thermal cycler (Eppendorf, Hamburg, Germany) in 20 $\mu \mathrm{L}$ volume containing $2 \mu \mathrm{l}$ DNA sample (100 $\mathrm{ng} / \mu \mathrm{l}), 1 \mu \mathrm{l}(10 \mathrm{pmol})$ of each forward and reverse primer, $10 \mu \mathrm{L}$ of DreamTaq Green PCR Master Mix (2X) (Thermo Scientific ${ }^{\mathrm{TM}}$, USA) and $7 \mu \mathrm{L}$ of nuclease free water (Thermo Scientific ${ }^{\mathrm{TM}}$, USA). A total of 40 PCR cycles were run with the following conditions: one initial denaturation cycle at $94^{\circ} \mathrm{C}$ for $3 \mathrm{~min}$, followed by 40 repeated cycles with temperatures at $94^{\circ} \mathrm{C}$ for $30 \mathrm{~s}$ (denaturation), $59^{\circ} \mathrm{C}$ for $30 \mathrm{~s}$ (annealing, specific for primers) and $72^{\circ} \mathrm{C}$ for $1 \mathrm{~min}$. After the final cycle, the preparations were kept at $72^{\circ} \mathrm{C}$ for $5 \mathrm{~min}$ for final elongation, and the PCR products were stored at $4^{\circ} \mathrm{C}$ in thermal cycler for further use (Sreedevi et al., 2012). Five microliters of PCR amplicons was analyzed on ethidium bromide stained $2 \%$ agarose gel (In Genius Gel documentation system, Syngene, UK). The sizes and quantities of PCR products were verified by comparison with a 100 bp plus quantitative ladder (Thermo Scientific ${ }^{\mathrm{TM}}$, USA)

\section{Results and Discussion}

Overall sero-prevalence of porcine cysticercosis in Dimapur and Kohimadistict was recorded as $3.00 \%$ (Table 2). Higherseroprevalence of porcine cysticercosis was recorded in Dimapur (3.33\%) compared to Kohima district $(2.67 \%)$ of Nagaland. These finding were in close conformity of Barua et al., (2018) where they recorded seroprevalence of porcine cysticercosis in 4 states of North EastIndiaas $2.72 \%$.

This might be because, in our study area, the vast majority of pigs are confined in pens, even among smallholders, compared to more extensive (i.e., free roaming and scavenging) pig husbandry practices which may predominate in the other study settings.

All the 360 pigs inspected at slaughter were from different market places of Dimapur and Kohima district of Nagaland, India (Fig. 2\& Fig. 3). The overall prevalence of porcine cysticercosis based on post-mortem inspection was $1.67 \%$ (Table 1). The prevalence was higher in Dimapur (2.22 \%) compared to Kohima district (1.67\%) of Nagaland.

Previously, Sarma (1977) recorded $6.64 \%$ positive cysticercosis from greater Guwahati of Assam. Plain (1991) recorded highest infection $11.90 \%$ infection from North Eastern region of Assam. Borkataki et al., (2012) conduct study in three districts of Assam for a period of one year and found 93 pigs $(9.50 \%)$ positive for cysticercosis out of 978 pigs. Although the previous workers recorded higher prevalence of porcine cysticercosis, Barua et al., (2018) recorded 
prevalence as $0.92 \%$ in 4 states of North East scavenging pigs from other parts of India as India. This might be due to importing of reported by butchers.

Table.1 Prevalence of porcine cysticercosis pigs of Dimapur and Kohima district of Nagaland

\begin{tabular}{|c|l|c|c|}
\hline District & Study area & Animals inspected(No.) & Cyst positive pig (\%) \\
\hline \multirow{3}{*}{ Dimapur } & Medziphema & 60 & $1(1.67 \%)$ \\
\cline { 2 - 4 } & Khuhboto & 60 & $2(3.33 \%)$ \\
\cline { 2 - 4 } & Nihokhu & 60 & $1(1.67 \%)$ \\
\hline \multirow{3}{*}{ Kohima } & Total & $\mathbf{1 8 0}$ & $\mathbf{4}(\mathbf{2 . 2 2 \% )}$ \\
\hline \multirow{3}{*}{} & Sechu-Zubza & 60 & $1(1.67 \%)$ \\
\cline { 2 - 4 } & Kohima & 60 & $0(0.00 \%)$ \\
\cline { 2 - 4 } & Zakhama & 60 & $1(1.67 \%)$ \\
\hline \multicolumn{2}{|r|}{ Total } & $\mathbf{1 8 0}$ & $\mathbf{2 ( 1 . 1 1 \% )}$ \\
\hline \multicolumn{2}{|c|}{ Overall Total } & $\mathbf{3 6 0}$ & $\mathbf{6}(1.67 \%)$ \\
\hline
\end{tabular}

Table.2 Sero-Prevalence of porcine cysticercosis in Dimapur and Kohima district of Nagaland

\begin{tabular}{|c|c|c|c|}
\hline District & Study area & No. of Pig Serum & Sero Positive (\%) \\
\hline \multirow{3}{*}{ Dimapur } & Medziphema & 50 & $2(4 \%)$ \\
\hline & Khuhboto & 50 & $2(4 \%)$ \\
\hline & Nihokhu & 50 & $1(2 \%)$ \\
\hline \multicolumn{2}{|r|}{ Total } & 150 & $5(3.33 \%)$ \\
\hline \multirow{3}{*}{ Kohima } & Sechu-Zubza & 50 & $2(4 \%)$ \\
\hline & Kohima & 50 & $1(2 \%)$ \\
\hline & Zakhama & 50 & $1(2 \%)$ \\
\hline \multicolumn{2}{|r|}{ Total } & 150 & $4(2.67 \%)$ \\
\hline \multicolumn{2}{|c|}{ Overall Total } & 300 & $9(3 \%)$ \\
\hline
\end{tabular}

Fig.1 Unloading of pigs in Dimapurbrought from Uttar Pradesh, India

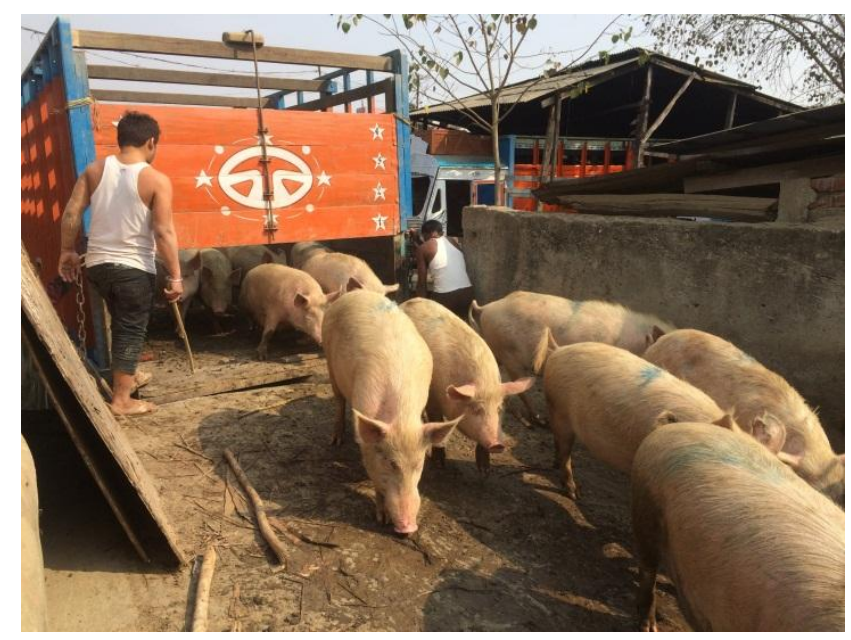


Fig.2 Cysts of Cysticercus cellulosae in skeletal muscle of pig carcass

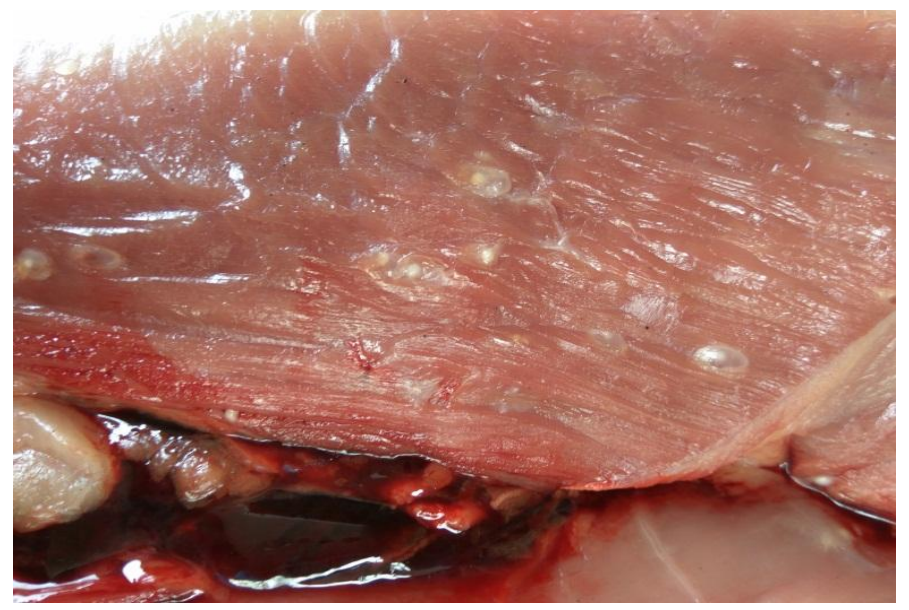

Fig.3 Cysts of Cysticercus cellulosae collected from tissue samples

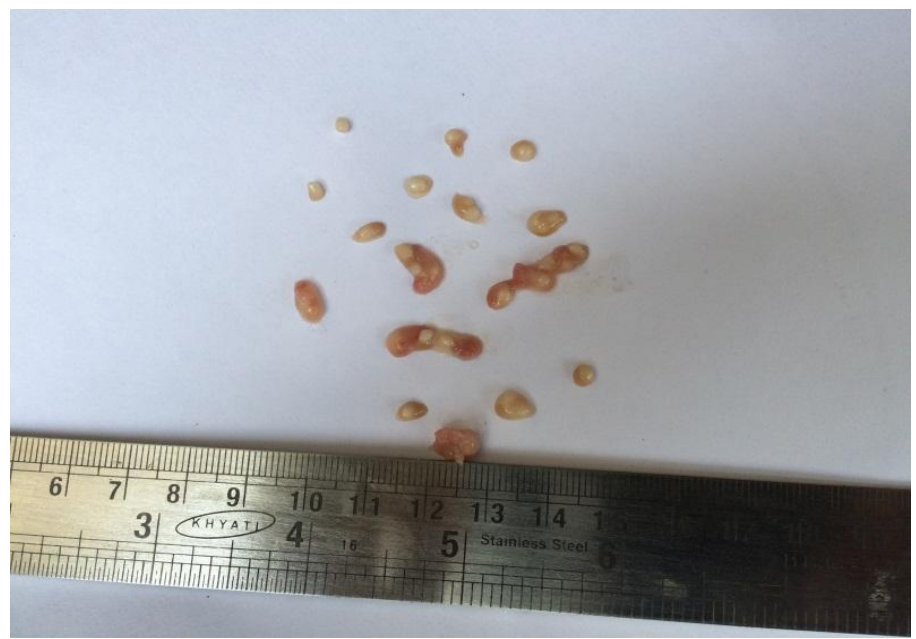

Fig.4 PCR asssay with TBR primers to detect Cysticercus cellulosae from pigcarcasses. Lane L: 100-bp DNA ladder; Lane 1 to 4: DNA samples extracted from cysticercosis positive pigs. Lane P: Positive control and Lane N: Negative control

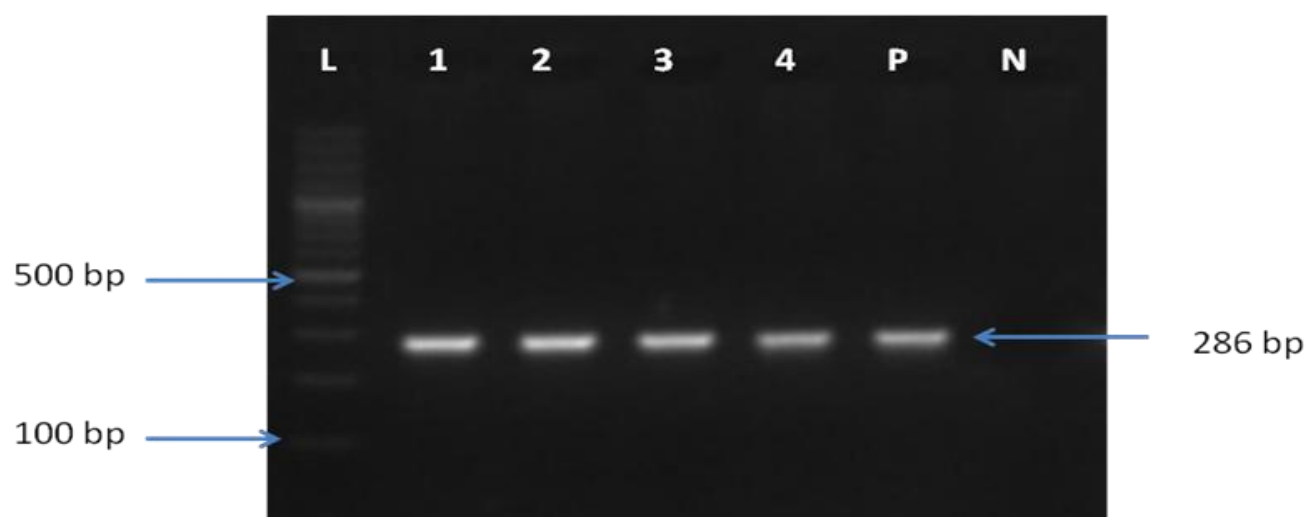


Identification of $T$. Solium cysticerci from the infected pig carcasses and suspected carcasses was based on amplification of large subunit rRNA gene (TBR) gene with a product size of 286 bp. All the positive cases show positive amplification of TRB gene (Fig. 4). Dalmasso et al., (2004) extracted DNA from degenerated and calcified cysts/lesions and found positive amplification for TRB gene. Lino Junior (2004) also reported the importance of PCR test with TBR primers as a reliable method for detection of cysticerci in tissues from human autopsies that are in advanced evaluative stages.

From the above study it was found that porcine cysticercosis is still a major public health concern. However there is less information regarding the prevalence of this disease has been recorded from North Eastern states of India. Therefore, an extensive study regarding the prevalence, transmission, risk factors and prevention of this neglected zoonotic disease is utmost concern.

\section{Acknowledgement}

Authors are thankful to ICAR, New Delhi for funding the "Outreach Project on Zoonotic diseases" and Director of Research (Veterinary) for necessary facilities to carry out the research. Due acknowledgement is also extended to the abattoir workers for providing samples.

\section{References}

Anonymous, 2012. Pork meat in India. www.g-e-f a.de/fileadmin/termine.../ Pork_Meat_in_India_-_Report.pdf.

Barua A., Raj H., Goswami C., Sonowal D. And Rajkhowa U., 2018. Prevalence of Porcine Cysticercosis in Four States of North East India. International Journal of Livestock Research, 8(10): 212-218.
Cai X.P., Zheng Y.D., Luo X.N., Jing Z.Z., $\mathrm{Hu}$ Z.M. and Lu C.P., 2006. Immunodiagnosis of cysticercosis in China. The Journal of Applied Research, 6(1): 69-76.

Dalmasso A., Fontanella E., Piatti P., Civera T., Rosati S., Bottero M.T., 2004. A multiplex PCR assay for the identification of animal species in feedstuffs. Molecular and Cellular Probes, 18: 81-87.

Deckers, N., Kanobana, K., Silva, M., Gonzalez, A.E., Garcia, H.H., Gilman, R.H. and Dorny, P., 2008. Serological responses in porcine cysticercosis: a link with the parasitological outcome infect. Int. J. Parasitol., 38: 1191-1198.

Deplazes P., Grimm F., Sydler T., Tanner I. and Kapel C.M.O., 2005. Experimental alveolar echinococcosis in pigs, lesion development and serological follow up. Veterinary Parasitology, 130: 213-222.

Geysen D., Kanobana K., Victor B., Rodriguez-Hidalgo R., De Borchgrave J. and Brandt J., 2007. Validation of meat inspection results for Taenia saginata cysticercosis by PCR restriction fragment length polymorphism. Journal of Food Protection, 70(1): 236-240.

Jardim E.A.G.V., Linhares G.F.C., Torres F.A.G., Araujo J.L.B. and Barbosa S.M., 2006. Diferenciacaoe specifica entre Taenia saginata e Taenia solium porensaio de PCR e duplex PCR. Specific discrimination between Taeniasaginata and Taenia soliumby one step PCR assay and duplex PCR. Ciencia Rural, Santa Maria, 36(1):166172.

Kedra A.H., Tkach V.V., Swiderski Z. and Pawowski Z., 2001. Intraspecific variability among NADH dehydrogenase subunit 1sequences of Taenia hydatigena. Parasitology International, 50: 145-148. 
Kolesarova M., Herich R., LevkutJr. M., Curlik J. and Levkut M., 2012. Suitability of different tissue fixatives for subsequent PCR analysis of Cysticercusovis. Helminthologia., 49(2): 67-70.

Lino Junior R.S., 2004. Cysticercosis diagnostic methods in autopsies. Revista do Instituto de Medicina Tropical de São Paulo, 46(3): 138.

Pinto P.S.A., Vaz A.J., Germano P.M.L. and Nakamura P.M., 2000. ELISA test for the diagnosis of cysticercosis in pigs using antigens of Taenia solium and
Taenia crassiceps cysticerci. Revista do Instituto de Medicina Tropical de Sao Paulo, 42(2): 71-79.

Sreedevi C., Hafeez M., Kumar P.A., Rayulu V.C., Subramanyam K.V. and Sudhakar K., 2012. PCR test for detecting Taenia solium cysticercosis in pig carcasses. Tropical Animal Health Production, 44: 95-99.

Willingham III A.L., Harrison L.J., Fevre E.M. and Parkhouse M.E., 2008.Inaugural meeting of the cysticercosis working group in Europe. EID J Home, 14(12).

\section{How to cite this article:}

Acheenta G. Barua, Koushik Kakoty, Pranjal M. Nath and Nur Abdul Kader. 2019. Detection of Porcine Cysticercosis in Nagaland of North East, India. Int.J.Curr.Microbiol.App.Sci. 8(08): 2590-2596. doi: https://doi.org/10.20546/ijcmas.2019.808.301 